\title{
Sobre el sentido y alcance del artículo 291 del Código Penal*
}

\author{
Jean Pierre Matus Acuña*
}

\begin{abstract}
RESUMEN
Se estudia en este trabajo el sentido y alcance del artículo 291 del Código Penal, prestando especial atención a si dicha figura penal es o no aplicable a la emisión de material particulado (polvo en suspensión y material particulado sedimentable) por las plantas chancadoras de cobre, material que en parte suele depositarse, por efecto de la acción del viento, en la geografía del lugar, en predios colindantes con dichas plantas. Al respecto, se concluye que tales hechos no se adecuan a la figura típica del delito del artículo 291 del Código Penal, y por lo tanto, son atípicos y no constitutivos de delito, como lo demuestra un estudio detallado del sentido y alcance de dicha disposición, según se expondrá a continuación.
\end{abstract}

Delito ecológico - derecho penal chileno - contaminación

\section{On the meaning and scope of Article 291 of the Chilean Criminal Code}

\begin{abstract}
This paper studies the meaning and scope of Article 291 of the Chilean Criminal Code. It pays particular attention to the applicability of that criminal offense to the emission of particulate matter (fine dust and settleable particulate matter) by copper crusher plants, which usually is deposited on the land adjacent to such plants due to the action of wind on the geography of the place. In this regard, a detailed study of the meaning and scope of the provision is carried out and it is concluded that the aforementioned facts do not fit the Article 291, and therefore, do not constitute an offence.
\end{abstract}

Environmental offence - Chilean criminal law - pollution

* El texto corresponde sustancialmente a la investigación que sirvió de base para mi opinión científica expresada en un Informe en Derecho, en una causa que el solicitante ha preferido mantener en reserva, por lo que se ha omitido toda referencia al caso concreto origen del mismo.

** Abogado, Doctor en Derecho, Profesor Titular de Derecho Penal en las Facultades de Derecho Universidad de Chile y Universidad Finis Terrae, Santiago de Chile. Correo electrónico: jean.matus@gmail.com

Artículo recibido el 30 de marzo de 2013 y aceptado para su publicación por el Comité Editorial el 28 de octubre de 2013. 


\section{Determinación del Sentido y alCanCe del artículo 291 Del Código Penal}

$\mathrm{E}$ 1 delito del actual artículo 291 del Código Penal, incorporado a la legislación nacional por medio del $\mathrm{N}^{\circ} 3$ del artículo único de la Ley $\mathrm{N}^{\circ} 18.765$, de 9 de diciembre de 1988, sanciona con presidio menor en su grado máximo, a

"los que propagaren indebidamente organismos, productos, elementos o agentes químicos, virales, bacteriológicos, radiactivos, o de cualquier otro orden que por su naturaleza sean susceptibles de poner en peligro la salud animal o vegetal o el abastecimiento de la población".

Como hemos dicho en otro lugar, esta disposición sería una de las escasas figuras del Derecho chileno en "donde aparece mejor recogida la idea del castigo de la emisión indebida de un contaminante, en los términos del artículo $2^{\circ}$ de la Ley $\mathrm{N}^{\circ} 19.300$ "

En efecto, se trataría de uno de los pocos casos, junto con el del artículo 136 de la Ley General de Pesca y Acuicultura, donde se establece un delito de contaminación, esto es, una conducta consistente en propagar en el ambiente sustancias que, por su naturaleza, sean susceptibles de poner en peligro la salud animal o vegetal o el abastecimiento de la población, siempre que ello se haga indebidamente, esto es, "en concentraciones o concentraciones y permanencia superiores o inferiores, según corresponda, a las establecidas en la legislación vigente".

Sin embargo,

"la falta de una clara identificación de los deberes jurídicos que debieran infringirse para cometer el delito, hace de muy difícil aplicación práctica la fórmula utilizada por el legislador; ello, sin contar con la dificultad adicional de probar la propagación de tales sustancias y, sobre todo, su capacidad (una vez propagadas) para poner en peligro la salud animal o vegetal o el abastecimiento de la población"².

A ello se suma que, aparte del texto especializado a que se ha hecho referencia y una memoria de grado dirigida por mí en el curso de la investigación que sirvió de base para su elaboración ${ }^{3}$, la doctrina nacional no se ha ocupado en su mayoría del tema, salvo por una referencia menor en el texto de estudio de Vivian Bullemore ${ }^{4}$ y un artículo de los autores españoles José Muñoz L. y José Ángel Fernández C., elaborado a partir de un Informe en Derecho que presentaran en la causa R.U.C. No $0400438154-3$ sobre la

${ }^{1}$ Matus, J. P. (Ed.), Derecho penal del medio ambiente. Estudios y propuesta para un nuevo Derecho penal ambiental chileno, Santiago: Ed. Jurídica de Chile, 2004, p. 208.

${ }^{2}$ Matus, Derecho penal del medio ambiente, p. 209.

${ }^{3}$ Quiroga, S.; Troncoso, R., Análisis de delitos de carácter ambiental contenidos en el Código Penal y las leyes especiales chilenas, Tesis UTAL, Talca: 2002 (Prof. Guía: Matus, J.P.).

${ }^{4}$ Bullemore, V., Curso de Derecho Penal, Vol. 3, Santiago: LegalPublishing, 2007, p. 256. 
posible responsabilidad penal en la contaminación del Santuario de la Naturaleza Carlos Anwandter en el río Cruces (Valdivia) ${ }^{5}$.

Es, además, indicativo de las dificultades de aplicación de la disposición del artículo 291 del Código Penal antes mencionadas el hecho de que revisadas las bases de datos de jurisprudencia que son públicas (Microjuris y Legalpublishing), no existen antecedentes de formalizaciones, condenas o sobreseimientos que permitan tener una idea de los límites que jurisprudencialmente se hayan establecido para esta figura típica.

Dicho lo anterior, cabe pasar a estudiar detalladamente el origen, bien jurídico y los requisitos de la figura típica, para posteriormente determinar si los hechos denunciados se adecuan o no a ellos, lo que aquí se rechaza por las razones que se expondrán.

\subsection{Origen de la disposición. Historia de su establecimiento}

La consagración legislativa del actual artículo 291 del Código Penal se originó en "Mensaje" del entonces Ejecutivo de 4 de mayo de 1988, que con motivo de la aparición de la fiebre aftosa en la frontera argentina, señalaba la necesidad de estudiar una modificación de la legislación vigente en la materia "ante la apremiante necesidad de otorgar una más eficaz protección jurídica a la salud de la población, la Seguridad Nacional y el patrimonio económico y ecológico del país”, agregando:

"El estudio realizado hizo evidente el imperativo de revisar la normativa penal vigente relativa a los delitos que atentan contra la salud animal y vegetal, y a la vez puso de manifiesto un vacío existente en la Ley $\mathrm{N}^{\circ} 18.314$, en cuanto a la posibilidad, no remota, de concretarse actos de esta naturaleza mediante la propagación, con propósito subversivo, de elementos virales, bacteriológicos y otros similares, susceptibles de causar grave daño a la salud de la población o la economía nacional"6.

En el "Informe Técnico" que acompaña a este "Mensaje" no se explica directamente el sentido de este vacío. Pero se da a entender que, teniendo en cuenta que los entonces vigentes artículos 289 a 291 del Código Penal hacían referencia a la conducta de propagar enfermedades animales o plagas que generalmente se transmiten llevando a los animales o vegetales enfermos a un lugar donde estas enfermedades o plagas no se encontraban presentes, la conducta que se pretendía tipificar consistiría básicamente en propagar sustancias capaces de causar enfermedades o plagas con efectos igualmente

${ }^{5}$ Muñoz Ll., J.; Fernández C., J.A., "Estudio dogmático penal de los artículos 291 del Código Penal y 136 de la Ley General de Pesca y Acuicultura. A propósito del caso del Santuario de la Naturaleza Carlos Anwandter", Política Criminal, Vol. 5, No 10 (2010), A4, pp. 410-454. Es importante mencionar que, como allí se explica, no todas las conclusiones del Informe origen de este artículo fueron compartidas por el Ministerio Público en la causa en que se presentó, al punto de haberse ejercido por este la facultad de "no perseverar", en el proceso, sin haberse formalizado a ninguna persona como responsable de los hechos que en el Informe de los autores se consideraban constitutivos del delito que analizamos (p. 413).

${ }^{6}$ Junta de Gobierno, Secretaría de Legislación, Ley $N^{\circ}$ 18.765, publicada en el Diario Oficial de 9-12-88, impreso de la Biblioteca del Congreso Nacional, p. 9. 
perniciosos e incontrolables a la masa pecuaria y vegetal del país sin necesidad de ser transmitidas por otros animales o por otras plantas y que, por lo mismo, podrían llegar a considerarse atentados terroristas, ya que

"Dados los avances tecnológicos experimentados en el último tiempo, los organismos, productos, elementos o agentes a que se refiere la norma impuesta pueden transformarse en un arma sumamente eficaz, si se emplean indebidamente, para dañar o debilitar los recursos biológicos del país"7.

El proyecto fue enseguida informado el 31 de mayo por el Secretario de Legislación de la Junta de Gobierno, quien hizo hincapié que en la conducta de propagar "elementos o agentes radiactivos, bacteriológicos, virales u otras formas igualmente letales 'subyacen' las características generales de los actos terroristas, tales como métodos ostensiblemente crueles, lesión o daño indiscriminado e instauración de un clima de terror y alarma pública”. A ello agrega, sin embargo, que, por esta misma razón, "resulta dudosa la inclusión de los actos contra la sanidad animal o vegetal”, pues "solo revestirán verdaderamente carácter terrorista cuando la enfermedad animal o la plaga vegetal puedan redundar en un grave peligro para la vida o la salud de las personas”. Y añade que a pesar de la especificación de tratarse de elementos que sean susceptibles de poner en peligro o causar grave daño a la salud animal o vegetal, "ello no necesariamente implicaría pánico o terror, mientras no amenace la salud humana”, ejemplificando con la fiebre aftosa como enfermedad que, de ser propagada, puede afectar gravemente la ganadería sin que "de ningún modo podría estimarse un delito terrorista" 8 .

Producto de esta observación, el Ejecutivo, entonces representado por el Ministerio del Interior, propuso el 15 de julio de 1988 modificar la norma en examen, "sustituyendo la referencia a la salud animal y vegetal por el abastecimiento de la población" 9 . La indicación sustitutiva de 7 de septiembre de 1988, enviada por quien ocupaba entonces el cargo de Presidente de la República, mantuvo esta nueva redacción que no consideraba entre los bienes jurídicos protegidos la salud animal y vegetal y hacía énfasis, en cambio, en el aspecto "terrorista" de la conducta que se pretendía sancionar.

El 30 de septiembre de 1988 el Proyecto fue analizado por la "Comisión Conjunta" y remitido a la "Junta de Gobierno", cambiando el texto y ubicación del propuesto nuevo número 17 del artículo $1^{\circ}$ de la Ley $\mathrm{N}^{\circ} 18.314$, pues “estimó más adecuado ampliar la figura penal vigente contenida en el $\mathrm{N}^{\circ} 8$ del artículo $1^{\circ}$ de la Ley $\mathrm{N}^{\circ} 18.314$, agregándole los nuevos agentes causantes de este delito propuestos por el Ejecutivo, en vez de incorporarle un nuevo $\mathrm{N}^{\mathrm{0}} 17$ como venía propuesto" ${ }^{10}$.

\footnotetext{
${ }^{7}$ Junta de Gobierno, Ley $N^{\circ} 18.765$, p. 14.

${ }^{8}$ Junta de Gobierno, Ley $N^{\circ} 18.765$, p. 53s.

${ }^{9}$ Junta de Gobierno, Ley $N^{\circ} 18.765$, p. 60.

${ }^{10}$ Junta de Gobierno, Ley $N^{\circ} 18.765$, p. 123.
} 
Sin embargo, la Junta de Gobierno no estuvo de acuerdo con el texto remitido y ordenó su reestudio, con el propósito de "contemplar la conducta prevista en el artículo $2^{\circ}$ del proyecto, como artículo 291 del Código Penal”, esto es, como un delito contra la salud animal o vegetal, lo que fue puntualmente obedecido por la "Comisión Conjunta", señalando que

"En efecto, en el tipo penal consignado en el artículo $2^{\circ}$ del proyecto, lo que se está penando es una conducta atentatoria contra la salud animal o vegetal o el abastecimiento de la población.

Si a través de esta conducta se producen otros efectos, como sería la lesión de la salud pública, lesiones corporales o muerte de una persona, se aplicarán las normas de los artículos 74 o 75 del Código Penal, en su caso"11.

Aunque en el documento proporcionado por la Biblioteca del Congreso Nacional se hace referencia a que las modificaciones sugeridas por la Junta de Gobierno habrían de hacerse "al tenor de las observaciones formuladas en la Sesión" de 11 de octubre de 1988, estas no se encuentran transcritas, por lo que es difícil ahondar más en las razones que originaron este cambio, como no sea lo que se deduce objetivamente: que se retiran como bienes jurídicos la vida e integridad de las personas; y en su lugar, se vuelve a configurar el delito como uno contra la salud animal o vegetal, añadiendo el "abastecimiento de la población" como uno de los bienes jurídicos a proteger.

De este modo, el proyecto así modificado, que corresponde a la literalidad del actual artículo 291 del Código Penal, tras la tramitación correspondiente, terminó por ser aprobado por la Junta de Gobierno el 3 de noviembre de 1988 y, sin recibir mayores observaciones, fue promulgado el 20 de noviembre de 1988 y publicado como número $3^{\circ}$ del artículo único de la Ley $\mathrm{N}^{\circ} 18.765$, de 9 de diciembre de 1988.

En resumen, durante la tramitación de la Ley $\mathrm{N}^{\circ} 18.765$, que estableció el actual artículo 291 del Código Penal, la prevalencia que se le dio a la afectación de la salud animal o vegetal como bien jurídico protegido, junto con el abastecimiento de la población, determinó su configuración y ubicación actual en vez de la inicialmente propuesta, como una forma especial de conducta "terrorista". Sin embargo, ello no afectó a la configuración de su forma de ejecución y objeto material: propagar sustancias que, por su naturaleza, pueden poner en riesgo la salud animal o vegetal o el abastecimiento de la población, sin que sean propagados necesariamente por otros animales o plantas enfermos o infectados, casos regulados en los artículos 289 y 290 del Código Penal.

${ }^{11}$ Junta de Gobierno, Ley $N^{\circ} 18.765$, p. 140s. El proyecto modificado en idénticos términos al actual artículo 291 del Código Penal se encuentra en la p. 143. 


\subsection{Bien jurídico protegido y estructura y naturaleza del delito del artículo 291 del Código Penal}

\subsubsection{Bien jurídico protegido}

Como se ha escrito en otra ocasión, cuando indagamos acerca del bien jurídico protegido por una disposición cualquiera, lo hacemos en su sentido sistemático, esto es, como el objeto de protección jurídica que ha de suponerse en una legislación racional y que, por lo mismo, "constituye el punto de partida y la primera pregunta en la indagación acerca del ámbito de aplicación de una determinada figura ilícita"12.

En este sentido, según acabamos de reseñar, el principal cambio que sufrió la disposición estudiada durante su trámite en la Junta de Gobierno fue la mutación de su objeto jurídico de protección o bien jurídico protegido, pasando de considerarse un delito de carácter terrorista a uno de peligro de afectación de la salud animal o vegetal o de provocar un desabastecimiento en la población, ubicándosele como artículo 291 dentro del $§ 9$ del Título VI del Libro II del Código Penal, delitos relativos a la salud animal y vegetal, incorporándose al Código junto con las modificaciones de penalidad del artículo 289 y el nuevo delito de introducción ilícita de animales que padecen enfermedades infecciosas del artículo 290.

Estos dos últimos artículos, así como el epígrafe del párrafo en que se ubican, fueron introducidos anteriormente por el artículo $2^{\circ}$ de la Ley $\mathrm{N}^{\circ} 17.155$, de 11 de junio de 1969, que modificó sustancialmente el Código en materia de delitos contra la salud pública y, en especial, los que en su redacción original el Código denominaba simples delitos relativos a las epizootias, esto es, las enfermedades infecciosas de los animales en los casos de epidemias declaradas, según rezaba el primitivo epígrafe del $§ 9$ del Título VI de su Libro II $^{13}$. Según quedó constancia en la historia de la Ley $\mathrm{N}^{\circ} 17.155$, el propósito de esta modificación fue "evitar la propagación de las enfermedades de los animales y plagas vegetales", que se entendían "directamente relacionadas con la salud pública" 14 .

Este antecedente acerca del epígrafe en que se ubica la figura del actual artículo 291, epígrafe que no fue modificado con su incorporación, es de suma importancia a la luz del texto expreso del artículo en cuestión y de la propia historia de su establecimiento ya reseñada, para dar sentido al propósito del legislador de 1988 de conformidad a lo dispuesto en el artículo 22 del Código Civil ${ }^{15}$, en tanto es posible atribuirle la configuración de un delito contra la salud animal o vegetal o el abastecimiento de la

${ }^{12}$ Politoff, S.; Matus, J. P.; Ramírez, Ma . C., Lecciones de Derecho penal chileno. Parte general, $2^{\mathrm{a}}$ ed., Santiago: Ed. Jurídica de Chile, 2004, p. 70.

${ }^{13}$ Del Río, R., Derecho penal, T. III, 1935, Santiago: Ed. Nascimento, p. $244 \mathrm{~s}$.

${ }^{14}$ Informe de la Comisión de Constitución, Legislación y Justicia, Diario de Sesiones de la Cámara de Diputados, Sesión $41^{\text {a }}$ de 5.09.1967, p. 3478.

${ }^{15}$ Según el cual, "el contexto de la ley servirá para ilustrar el sentido de cada una de sus partes, de manera que haya entre todas ellas la debida correspondencia y armonía” (véase al respecto Matus, J.P., La Ley Penal y su Interpretación, 2a. ed., Santiago: Ed. Metropolitana, 2012, p. 192). 
población y no contra la salud individual de uno o varios especímenes animales o vegetales determinados ${ }^{16}$.

Esto es, se trata aquí de la protección de la salud animal y vegetal referida a la de las especies pecuarias y vegetales del país como un todo frente al peligro que para su subsistencia o productividad supone la propagación de enfermedades infectocontagiosas, plagas u otras sustancias que las ataquen de manera indiscriminada e incontrolada, y que, según su extensión, podría llegar a poner en riesgo la seguridad alimenticia o abastecimiento de la población.

Así, respecto de la salud animal, es apropiado decir, como sostienen los expertos internacionales en la materia, que esta puede ser "entendida no apenas como la eventual presencia o ausencia de una determinada enfermedad de etiología específica, sino como el conjunto de condiciones que determinan las características productivas de una población animal en un momento y espacio concretos" ${ }^{17}$, esto es, "la optimización de la capacidad productiva de una población animal en una región y momento dados" 18 .

Este es el sentido de nuestra Ley de Sanidad y Protección Animal, Decreto con Fuerza de Ley RR.AA. No 16, de 09.03.1963 y sus modificaciones posteriores, donde se protege la sanidad animal mediante las medidas sanitarias que allí se indican (inyecciones, asilamiento, secuestro, vacunaciones, desinfecciones, sacrificio de animales enfermos, etc. $\left(\right.$ Art. $\left.9^{\circ}\right)$, tendientes a evitar la propagación de enfermedades infectocontagiosas determinadas en el Reglamento (Art. $\left.1^{\circ}\right)^{19}$ y la eliminación de especímenes que "presenten taras hereditarias, anomalías morfológicas o un estado sanitario irrecuperable" (Art. $9^{\circ}$ bis); se establece el requisito de "cumplir con las exigencias sanitarias" que se determinen en cada caso para importar animales, aves, productos, subproductos y despojos de origen animal y del reino vegetal, y contar, en caso de importación de animales, "de un certificado expedido por la autoridad competente del país de origen, que acredite el estado sanitario de ellos" (Art. $3^{\circ}$ ); se hace obligatoria la inspección preventiva de

${ }^{16}$ En cambio, a pesar de encontrarse bajo el mismo epígrafe, el delito del artículo 291 bis, sobre "maltrato de animales", sí se refiere a la protección de la salud individual de los animales maltratados, lo que se desprende de lo siguiente: a) desde luego, en su propio texto, la norma del artículo 291 bis no hace referencia directa a la salud animal, como sí lo hace el artículo 291; b) su introducción al Código es posterior a las reformas de 1988; y c) su introducción no fue realizada, como en el caso del artículo 291, en el contexto de establecer sanciones más eficaces para prevenir los efectos de la fiebre aftosa, esto es, una enfermedad contagiosa que afecta la salud animal como un todo por ese carácter, y no solo la de los especímenes infectados, sino precisamente para el castigo del maltrato de especímenes determinados. Para un análisis más detallado de este delito, véase Matus, J. P., “Acerca de la licitud de las 'peleas de gallos' y el alcance del delito del artículo 291 bis del Código Penal”, Gaceta Jurídica, No 370 (2011), pp. 13-24, y las referencias que allí se indican.

${ }^{17}$ Rosenberg, F.J., "Estructura social y epidemiología veterinaria en América Latina”, Boletín Panamericano de Fiebre Aftosa, Vol. 52 (1986), pp. 3-23, p. 3.

${ }^{18}$ Casas O., R.; Rosenberg, F.J.; Astudillo, V.M., "La producción y salud animal y sus interrelaciones con la salud pública veterinaria en América Latina y el Caribe”, Revue scientifique et technique (International Office of Epizootics), Vol. 10, No 4 (1991), pp. 1087-1100, p. 1087.

${ }^{19}$ Y este es el mismo sentido del Reglamento para la Aplicación de la Lei de Policia Sanitaria Animal, Decreto $\mathrm{N}^{\circ} 138$, de 15.04.1925. 
animales en Aduanas y su sometimiento a medidas de desinfección, vacunación, inyección, etc., en caso de ser necesario (Art. $4^{\circ}$ ); se prohíbe importar "animales y aves con taras o anomalías morfológicas que afecten su productividad" (Art. $4^{\circ}$ bis); y se obliga al dueño o tenedor de animales atacados por alguna de las enfermedades contagiosas que determinen el Reglamento o que ofrezcan sospechas de estarlo a denunciar "inmediatamente" el hecho a la autoridad (Art. 6 $6^{\circ}$, obligación que el Art. $7^{\circ}$ extiende a médicos veterinarios y funcionarios públicos ${ }^{20}$.

Este es el mismo sentido que tienen, en lo que respecta a la salud o sanidad vegetal, las disposiciones del Decreto Ley $\mathrm{N}^{\circ}$ 3.557, publicado en el Diario Oficial de 9 de febrero de 1982, que faculta al Servicio Agrícola y Ganadero para determinar periódicamente la nómina de plagas que estarán afectas a control obligatorio y decretar las medidas de control de los predios donde existan especies vegetales denunciadas como afectadas por una plaga, incluyendo la destrucción de sementeras, plantaciones o productos afectados (Arts. $4^{\circ}$ a $7^{\circ}$ ); y para decretar el control de cuarentena o aislamiento, eliminación, desinfección y desinfestación e industrialización de cualquier mercancía (incluyendo las semillas y desechos vegetales) afectada por una plaga vegetal o potencialmente capaces de constituir o transportar plagas (Arts. $1^{\circ}, 2^{\circ}, 9^{\circ}$ y $10^{\circ}$ y 18 a 25 ). Este sistema da cumplimiento a lo dispuesto en la Convención Internacional de Protección Fitosanitaria, adoptada por la Organización de las Naciones Unidas para la Agricultura y la Alimentación (FAO) en Roma, de 6 de diciembre de 1951 y cuyo texto revisado fue ratificado y promulgado como Ley de la República por Decreto Supremo N $^{\circ} 843$, publicado en el Diario Oficial de 6 de enero de 1987, donde en su artículo 1 se establece el propósito de los suscriptores en orden a "actuar eficaz y conjuntamente para prevenir la diseminación e introducción de plagas de plantas y productos vegetales y de promover medidas apropiadas para combatirlas".

Por lo tanto, podríamos definir la salud vegetal también como el estado de conservación, desarrollo y producción óptimos, de acuerdo con sus potencialidades genéticas, de las diferentes especies que componen la masa vegetal del país, no solo por encontrarse libre de plagas, sino también por el conjunto de condiciones que determinan sus características productivas en un momento y espacio concretos ${ }^{21}$.

En cuanto al abastecimiento de la población como bien jurídico protegido en esta figura, debido a la expresa voluntad del legislador de la época en orden a considerar este delito como uno que debería incorporarse al $§ 9$ del Título VI del Libro Segundo, el claro tenor literal de su epígrafe (delitos relativos a la salud animal y vegetal), y las

${ }^{20}$ En cambio, el artículo $2^{\circ}$ de dicha Ley de Sanidad y Protección Animal, al prohibir las lidias de toro, actividades que no afectan la sanidad animal, apunta precisamente a ese segundo objetivo de la regulación, esto es, la protección del bienestar de animales determinados, esto es, de su salud individual (como en términos generales hace también el artículo 291 bis del Código Penal).

${ }^{21} \mathrm{Y}$ de manera refleja, la salud individual de una planta específica, puede entenderse no solamente como su conservación libre de enfermedades o plagas, sino como el estado en el que "puede llevar a cabo sus funciones fisiológicas al óptimo de su potencial genético", lo que "constituye el propósito de una agricultura eficiente y productiva en todos los tiempos” (Ciampi, L., Introducción a la Patología Vegetal, Valdivia: U. Austral, 2002, p. 24). 
modalidades de su comisión (propagar sustancias químicas, radiactivas, virales, bacteriológicas, etc.), debe entenderse que el "peligro para el abastecimiento de la población" se refiere únicamente al abastecimiento de alimentos derivados de la actividad agropecuaria, esto es, a poner en peligro la seguridad alimentaria de la población. Según la Cumbre Mundial de Alimentación de 1996, promovida por la FAO, "existe seguridad alimentaria cuando todas las personas tienen en todo momento acceso físico y económico a suficientes alimentos inocuos y nutritivos para satisfacer sus necesidades alimenticias y sus preferencias en cuanto a los alimentos, a fin de llevar una vida activa y sana". El peligro de "desabastecimiento" ha de referirse, por tanto, a una situación de peligro de disponibilidad de alimentos cuando, producto de una enfermedad, plaga u otra causa, no se producen en cantidades suficientes o, produciéndose, no están en condiciones de nutrir a la población como un todo en una zona más o menos extensa del territorio o son nocivos para ella ${ }^{22}$.

Por lo tanto, debemos entender que los bienes jurídicos protegidos específicamente por esta disposición son, directamente, la salud animal o vegetal; e indirectamente, el abastecimiento de la población, derivado de la afectación de los primeros. Se trata de especificaciones concretas del amplio concepto de protección de la biodiversidad en que se han enmarcado estas figuras ${ }^{23}$, cuya afectación opera de modo alternativo para configurar el delito ${ }^{24}$, aunque en su especificidad el "peligro de abastecimiento de la población" solo puede ser entendido como un peligro derivado de la afectación de la salud animal y/o vegetal, en el sentido ya explicitado de seguridad alimentaria ${ }^{25}$.

\subsubsection{Estructura típica: delito de peligro concreto complementado con la técnica de la ley penal en blanco}

En paralelo a las disposiciones que protegen la salud pública (humana), las que protegen la salud animal o vegetal se estructuran también como delitos de peligro concreto, donde se requiere "una efectiva sensibilización o conmoción del bien jurídico, que se juzga sobre la base de la experiencia común y que permite concluir (ex post) que existió

${ }^{22}$ Lo que puede ocurrir no solo cuando las especies animales o vegetales padecen enfermedades (epizootias) o plagas, sino también cuando son portadoras de los organismos que las causan sin desarrollarlas necesariamente, como en el caso de algunas zoonosis, esto es, "aquellas enfermedades transmisibles de forma natural de los animales vertebrados al hombre y viceversa" (Olea, A., "Zoonosis”, El Vigía. Boletín de Vigilancia en Salud Pública de Chile, Vol. 7, N 19 (2003), pp. 39-43).

23 Así en Matus, Derecho penal del medio ambiente, p. 208 y Bullemore, Curso, Vol. 3, p. 256.

${ }^{24}$ Muñoz y Fernández, "Estudio dogmático”, p. 423, autores que, sin embargo, y pese a la declarada importancia que le asignan a la determinación de los bienes jurídicos protegidos y su forma de afectación en este delito, no solo omiten todo análisis acerca de su contenido, sino que tampoco ofrecen siquiera una definición operativa de los mismos, que sea contrastable con las conclusiones a que aquí hemos arribado.

${ }^{25}$ Así, aunque bien podría afirmarse que también se pone en riesgo el "abastecimiento de la población” por acciones de carácter económico o político (mercado negro, paralizaciones de la producción o el transporte, etc.), este riesgo no está abarcado por la figura penal en estudio, por la expresa vinculación que hace el artículo 291 del Código Penal entre la salud animal, la vegetal y el abastecimiento de la población. 
un curso probable que conducía al resultado temido (el que fue impedido por un factor con el que no era seguro contar)" 26 .

En este caso, la prohibición de la conducta punible ("propagar determinadas sustancias") solo adquiere pleno sentido cuando ella pone en peligro concreto la salud animal o vegetal o el abastecimiento de la población, lo que se determina, según la ley, no por la forma o modo de ejecución de la conducta, sino por el objeto material sobre el que recae, esto es, sustancias que por su naturaleza son susceptibles de provocar el peligro que se quiere evitar. Luego, el peligro que debe demostrarse para configurar el delito radica en la naturaleza de las sustancias que se propagan.

Por lo tanto, los elementos típicos característicos de la figura son la conducta de propagar un determinado objeto que, por su naturaleza, sea susceptible de poner en peligro la salud animal o vegetal o el abastecimiento de la población.

Lo anterior significa que no todo propagar sustancias que eventualmente causen daño al ambiente es delictivo a este título, sino solo el propagar aquellas sustancias que, por su naturaleza, son susceptibles de poner en peligro la salud animal o vegetal o el abastecimiento de la población, esto es, alguno de los bienes jurídicos protegidos por la norma.

Y, además, siempre que dicha conducta sea indebida, esto es, realizada con infracción de algún deber o quebrantamiento de alguna prohibición legalmente establecido. En este sentido, Muñoz y Fernández describen acertadamente la función de la expresión indebidamente como la consagración de una ley penal en blanco mediante una remisión al resto del ordenamiento para determinar la medida de lo permitido en el caso concreto ${ }^{27}$.

En cambio, la opinión de Muñoz y Fernández, en el sentido de que este delito tendría una estructura diferente a la aquí expuesta, en la que "la conducta punible" consistiría no en el verbo activo "propagar", sino en la propagación indebida de sustancias, un "resultado" que "debe mostrar una virtualidad suficiente para poner en peligro la salud animal o vegetal, o el abastecimiento de la población" (los destacados son de los autores) ${ }^{28}$, parece constituir una propuesta no de interpretación del texto legal, sino de analogía in malam partem, pues con ella se extiende la punibilidad más allá de los límites del sentido literal posible del texto interpretado, a casos no contemplados en la disposición, específicamente, a supuestos de simple emisión directa o indirecta de las sustancias que se trata al ambiente (sin que el agente sea el que las "propague") y hasta su comisión por omisión ${ }^{29}$, los cuales no son compatibles con el límite que impone a la interpretación el empleo por la ley de la expresión "propagaren”, forma verbal activa cuyo sentido es meridianamente claro en el lenguaje y diferente a su resultado ("propagación”).

Es cierto que en otras legislaciones, como la española, es posible afirmar, de conformidad con el texto del artículo 325 del Código Penal español, que existe una figura genérica de contaminación donde la ley atiende al resultado antes que la actividad del

\footnotetext{
${ }^{26}$ Politoff, Matus y Ramírez, Parte general, p. 210.

${ }^{27}$ Muñoz y Fernández, "Estudio”, p. 425.

${ }^{28}$ Muñoz y Fernández, "Estudio”, p. 422,

${ }^{29}$ Muñoz y Fernández, “Estudio”, pp. 433-435.
} 
agente para describir la conducta punible, pues allí lo que se castiga es provocar o realizar emisiones directa o indirecta de contaminantes ${ }^{30}$. Pero ello no autoriza al intérprete a trasponer el sentido de dicha figura legal en algún tipo penal chileno que no ha sido concebido en sus mismos o siquiera parecidos términos lingüísticos, aunque se refieran a materias similares.

En efecto, aunque también es cierto que, como ya hemos sostenido, la figura del artículo 291 del Código Penal puede verse, desde un punto de vista más amplio, como una de las pocas que sancionaría en Chile la contaminación por emisión de sustancias tóxicas o peligrosas, del mismo modo lo es que su configuración típica, según el texto de la ley, no permite sin más suponer que la modalidad que comprende es una suerte de especificación sin consecuencias típicas de una figura genérica de contaminación prelegislativa no establecida aún de manera expresa en la ley chilena, pero subyacente a este delito y al del artículo 136 de la Ley General de Pesca y Acuicultura, misma figura prelegislativa que se reflejaría en el texto expreso del artículo 325 del Código Penal español, de manera que pueda trasponerse sin dificultades el sentido de este último texto legal en los patrios: una cosa es una apreciación general de las potencialidades de una disposición como un caso específico de contaminación punible, y otra bien distinta su configuración legal específica, en cuyo análisis el intérprete se encuentra vinculado por el sentido literal posible de las palabras empleadas para ello por el legislador, límite fundamental impuesto por principio de legalidad, consagrado constitucionalmente (artículo $19 \mathrm{~N}^{\mathrm{o}} 3$, inciso $8^{\circ}$ de la Constitución Política de la República), y que impide a la hora de interpretar una ley sustituir sus palabras expresas por otras más acordes con la teoría o los modelos regulativos de otras naciones, extendiendo su aplicación a casos no contemplados en ella, pero similares (y aún dignos de igual protección).

En palabras de Roxin,

"El principio 'no hay delito sin ley' permite escaparse colándose entre las mallas de la ley penal. Por eso Franz v. Liszt denominó al Código Penal, que realmente debería servir para combatir el delito, con una fórmula exagerada pero pegadiza, 'la Carta magna del delincuente'. Ello significa lo siguiente: que así como en su momento la 'Magna Charta Libertatum' británica (1215) protegía al individuo de intromisiones arbitrarias del poder estatal, el Código Penal pone a cubierto al ciudadano (tanto al honrado como al no honrado) de todo castigo por una conducta que no haya sido claramente declarada punible antes del hecho. Que con ello en alguna ocasión pueda quedar impune una conducta especialmente refinada, socialmente

\footnotetext{
30 “Artículo 325. Será castigado con las penas de prisión de dos a cinco años, multa de ocho a veinticuatro meses e inhabilitación especial para profesión u oficio por tiempo de uno a tres años el que, contraviniendo las leyes u otras disposiciones de carácter general protectoras del medio ambiente, provoque o realice directa o indirectamente emisiones, vertidos, radiaciones, extracciones o excavaciones, aterramientos, ruidos, vibraciones, inyecciones o depósitos, en la atmósfera, el suelo, el subsuelo o las aguas terrestres, subterráneas o marítimas, incluido el alta mar, con incidencia incluso en los espacios transfronterizos, así como las captaciones de aguas que puedan perjudicar gravemente el equilibrio de los sistemas naturales. Si el riesgo de grave perjuicio fuese para la salud de las personas, la pena de prisión se impondrá en su mitad superior".
} 
nociva y por ello merecedora de pena, es el precio que ha de pagar el legislador por la falta de arbitrariedad y la seguridad jurídica (es decir, por la calculabilidad de la aplicación de la potestad punitiva del Estado)"31.

Sin embargo, se podría oponer a lo anterior que, en realidad, la propuesta sustitución del verbo rector del artículo 291 del Código Penal, que denota una actividad ("propagaren”), por un sustantivo resultativo ("propagación”), podría responder mejor a la protección de los bienes jurídicos en juego, lo que se encontraría en los márgenes de una interpretación extensiva lícita.

Según la doctrina dominante entre nosotros, habría una interpretación extensiva admisible allí donde "la aplicación de las reglas interpretativas" a una disposición penal determinada "nos lleva a la conclusión de que, en su verdadero sentido, la ley comprende también ciertos casos que aparentemente no están incluidos en el tenor literal mismo del precepto" porque "el lenguaje empleado no fue claro o resultó poco feliz", pero "el sentido de la ley es indiscutiblemente el de incluir el caso (no el propósito de la ley, sino su voluntad o sentido)"32. Y el propio Tribunal Constitucional ha admitido expresamente la licitud de una interpretación amplia o extensiva de las leyes penales, declarando que el juez es libre para determinar el sentido y alcance de un precepto legal, siempre que lo haga dentro de los límites del tenor literal del texto interpretado, es decir, "construya su razonamiento a partir del texto legal y no cree una figura delictiva sin base normativa de sustentación"33.

En este sentido, la corrección una propuesta normativa como resultado de la interpretación, llámesele interpretación extensiva o restrictiva, supone que esta se encuentre dentro de las posibilidades semánticas del sentido literal de la norma interpretada y no más allá o más acá de ella, respectivamente. Esta es la esencia del principio de legalidad a partir del cual se cimenta toda interpretación. Luego, la corrección o correspondencia con el sentido literal posible de la disposición interpretada, su tenor literal en términos del Tribunal Constitucional, es la base del trabajo interpretativo. Dentro de dicho sentido literal posible se puede recurrir a argumentos teleológicos o sistemáticos para delimitar el alcance de la norma interpretada, especialmente en casos de oscuridad de las expresiones que el legislador emplea, pero no corresponde al intérprete sustituir las palabras de la ley para ofrecer una interpretación de los términos con que sustituye los originales

${ }^{31}$ Roxin, C., Derecho penal, parte general, 2a ed., T. I., Trad. Muñoz Ll. et al., Madrid, Civitas, 1997, p. 138.

32 Etcheberry, A., Derecho penal, T. I., $3^{\text {a }}$ ed., Santiago, Ed. Jurídica de Chile, 1997, p. 109).

${ }^{3}$ STC 13.08.2009, Rol 1281, Cons. 23-25. En el caso se discutía si podían entenderse comprendidas dentro de la expresión "aguas” del artículo 459 del Código Penal las aguas “subterráneas”, alegando la defensa que hacerlo de ese modo sería realizar una interpretación extensiva que provocaría efectos contrarios a la Constitución. En el razonamiento del tribunal subyace el hecho de que en el Código Penal no se distingue la naturaleza de las "aguas" que se trate y que estas tienen un contenido normativo que incluye tanto las superficiales como las subterráneas. Como se aprecia, la discusión gira en torno a la interpretación posible de un concepto legal, "aguas", y no sobre la posibilidad de sustituir este por otro más amplio, como sería afirmar que el artículo 459 del Código Penal castigase la usurpación de líquidos, incluyendo entre ellos, por ejemplo, los combustibles. 
legales, sino interpretar las palabras de la ley para fijar su verdadero sentido y alcance, aún en casos de no ser del todo claras.

Esta pretensión de corrección semántica es lo que explica por qué, en definitiva, aunque se admita la interpretación extensiva y restrictiva, ello solo se hace entendiendo que también esas formas de interpretación cumplen una función declarativa, esto es, que ellas sirven para fijar el verdadero sentido y alcance de la ley, no habiendo lugar para su extensión a casos fuera de ese sentido o su limitación a casos en él comprendidos basados en argumentos emotivos a favor o en contra del reo o el interés social que se quiera proteger, tal como dispone el artículo 23 del Código Civil ${ }^{34}$.

Desde esta perspectiva, la sustitución de las expresiones de un texto legal por otras para, a partir de esas diferentes expresiones, extender el alcance del precepto delimitado por su sentido literal posible, puede criticarse recurriendo a la apreciación de Ross, quien ha sostenido que la interpretación extensiva así entendida no sería más que una forma de analogía con un claro propósito político, como en el caso que aquí se discute:

\begin{abstract}
"Se habla de interpretación extensiva (interpretación por analogía) cuando las consideraciones pragmáticas se traducen en la aplicación de la regla a situaciones que, contempladas a la luz del sentido lingüístico natural, se encuentran claramente fuera de su campo de referencia" 35 .
\end{abstract}

Despejada la controversia planteada acerca del sentido de la voz activa "propagaren" y su, a mi juicio, incorrecta sustitución por el sustantivo resultativo "propagación", corresponde pasar ahora al análisis de los detalles de los elementos que configuran la tipicidad de este delito: los sujetos activos, la conducta, su objeto material y el elemento normativo referido a la antijuricidad que la configura.

\title{
1.3. Tipicidad
}

\subsubsection{Sujeto activo: "Los que propagaren"}

La disposición contempla un delito común, en el cual el sujeto activo no requiere calificación, característica personal o ser portador de un deber especial alguno. Ello es consecuencia del diseño de origen de la disposición, en que se piensa en un sujeto o un pequeño grupo de sujetos que, con el propósito de "subvertir" el orden, propagan sustancias que por su naturaleza pueden afectar la salud animal o vegetal o el abastecimiento de la población. Por lo tanto, no se trata de un delito de infracción de deberes especiales en el orden económico o productivo, sino de uno de puesta en peligro de los bienes jurídicos que se protegen por medio de la propagación de las sustancias radiactivas, virales, etc., a que se refiere la disposición.

\footnotetext{
${ }^{34}$ Véase al respecto Matus, Interpretación, p. 206, con amplias referencias en nota $\mathrm{N}^{\circ} 167$.

35 Ross, A., Sobre el Derecho y la Justicia, Buenos Aires, Eudeba, 1963, p. 144.
} 
Es importante destacar que, por lo dicho anteriormente, no se trata de un delito en que al configurarse se haya tenido en mente que sus autores habrían de ser principalmente los directivos y ejecutivos de empresas e industrias, como, al contrario, sucede con las propuestas sobre regulación de delitos de contaminación y contra el medio ambiente que se han presentado últimamente, tanto por la doctrina como en el Congreso y en el Anteproyecto de Código Penal de $2005^{36}$. Por lo tanto, las consideraciones respecto de la autoría mediata y la responsabilidad empresarial no tienen en este delito un lugar destacado ni reglas especiales, por lo que ha de estarse a lo que dice en las partes generales al uso para su evaluación en el caso concreto ${ }^{37}$.

Por otra parte, tampoco a los directivos y administradores de las empresas les son aplicables en este caso especiales deberes de cuidado, como los que ahora se exigen expresamente en la administración de personas jurídicas, en virtud de lo dispuesto en los artículos $3^{\circ}$ y $4^{\circ}$ de la Ley de Responsabilidad Penal de las Personas Jurídicas, $N^{\circ} 20.393$, de diciembre de 2010. En efecto, la expresa limitación del artículo $1^{\circ}$ de dicha Ley $\mathrm{N}^{\mathrm{o}} 20.393$ a ciertos delitos en particular (lavado de activos, financiamiento del terrorismo y cohecho de funcionarios públicos chilenos y extranjeros), no solo hace inaplicable la responsabilidad penal de las personas jurídicas al supuesto de esta disposición, sino que, además, por imposición del principio de legalidad constitucionalmente consagrado, hace imposible trasladar, por analogía en la interpretación del vigente artículo 58 del Código Procesal Penal, a personas naturales directivas de las jurídicas, los criterios de imputación de esta Ley, que establece la obligación de autorregulación empresarial,

36 Véase al respecto Matus, J. P., "Fundamentos y propuesta legislativa para una nueva protección penal del medio ambiente en Chile, elaborada por la Comisión Foro Penal”, Zeitschrift für internationales Strafrecht, $\mathrm{N}^{\circ} 7$ (2008), pp. 304-324. Allí se da cuenta de los proyectos legislativos entonces en tramitación y del Foro Penal, que recogían las ideas del autor antes expuestas en Matus, Derecho penal del medio ambiente, pp. 225-242, en orden a establecer un sistema de imputación top-down, donde la figura central o autor de los hechos de contaminación apareciese descrito en el tipo penal como el "responsable o administrador de un proyecto a actividad”, entendiendo por tales, tratándose de personas jurídicas, a los "representantes legales, gerentes o directores y, en general, todos quienes tengan o compartan de hecho o jurídicamente facultades de administración de la misma”. El texto apareció también, con leves modificaciones, en la Revista de Estudios Públicos, No 110 (2008), pp. 193-239, seguido de una exposición crítica de Bascuñán R., A. ("Comentario crítico a la regulación de los delitos contra el medio ambiente en el Anteproyecto de Código Penal de 2005”, pp. 241-321), especialmente, pp. 292-298. Lo interesante del comentario es que, detrás de los adjetivos y descalificaciones que en él se emplean para criticar la propuesta, el comentarista está de acuerdo que el propósito de la regulación penal ambiental moderna es poner en primera línea de imputación a quienes efectivamente dirigen las organizaciones empresariales donde esta tiene lugar, y que este es un asunto que debiera abordarse en una futura regulación, ya que no existen soluciones plausibles para ello en la actual.

${ }^{37} \mathrm{Al}$ respecto, véase Politoff, Matus y Ramírez, Parte general, pp. 402-414. Un resumen de las aportaciones de Feijoo en la materia puede verse en Muñoz y Fernández, "Estudio", pp. 439-443, donde se exponen con el expreso propósito de aplicarlas al análisis de casos concretos en relación con este artículo 291 del Código Penal, aunque se reconoce, en todo caso, que tratándose de un delito común, "no resultan necesarios especiales elementos o condiciones en la autoría". 
en orden a contar con modelos de prevención de los delitos por los que pueden hacerse responsables las personas jurídicas ${ }^{38}$.

En cuanto a los sujetos pasivos, el artículo 291 del Código Penal no considera como tales a personas determinadas, pues, como ya dijimos, se trata de un delito de peligro contra la salud vegetal o animal y el abastecimiento de la población. La afectación real a dichos bienes jurídicos no está contemplada como una modalidad del delito ni como una agravación de la conducta punible y el legislador decidió, para el caso más grave, y que excede los bienes referidos explícitamente en la disposición (afectación de la vida o la salud de las personas), se debiera recurrir a las normas concursales generales.

\subsubsection{La conducta: "propagar"}

Según las primeras tres acepciones del Diccionario, propagar es "multiplicar por generación u otra vía de reproducción”, "hacer que algo se extienda o llegue a sitios distintos de aquel en que se produce", o "extender, dilatar o aumentar algo".

Atendida la naturaleza del objeto material de este delito, parece descabellado, aunque no imposible, imaginar la situación del que multiplica, extiende o dilata sustancias susceptibles de poner en peligro la salud vegetal o animal o el abastecimiento de la población. Y por ello es preferible remitir la interpretación a la segunda acepción, que concibe la voz propagar como hacer que algo se extienda o llegue a sitios distintos de aquel en que se produce.

Se trata, por lo tanto, de un acto positivo en orden a hacer que las sustancias susceptibles de poner en peligro la salud animal o vegetal lleguen a otros sitios distintos de aquel en que se producen.

Es decir, no se castiga la mera tenencia, producción o aun la emisión de tales sustancias, sino el hecho de llevarlas materialmente (mediante un hacer positivo) a otros sitios distintos de los que se producen, de tal manera que el riesgo acotado inicial se extienda y pueda considerarse, por la naturaleza de tales sustancias, que puede ponerse en peligro la salud vegetal o animal o el abastecimiento de la población, que son los bienes jurídicos protegidos por la disposición.

De allí la gran diferencia antes anunciada con el delito de contaminación o ecológico del artículo 325 del Código Penal español, donde se castiga la emisión de cualquier clase de sustancias contrariando las disposiciones legales pertinentes. En efecto, según el Diccionario, emitir una sustancia es "arrojarla" o "echarla hacia fuera", lo que es independiente del hecho de propagarla, esto es, de llevarla a otro lugar distinto del que se emite. Y esta es la razón por la que nosotros afirmamos que no puede pretender reconducirse la interpretación del artículo 291 del Código a un delito de emisión indebida, aunque en general sí

\footnotetext{
${ }^{38}$ Sobre estos modelos y los restantes requisitos de imputación de delitos a las personas jurídicas en la legislación nacional, véase Matus, J. P., "Presente y futuro de la responsabilidad de las personas jurídicas por delitos cometidos por sus directivos y empleados", Revista de Derecho del Consejo de Defensa del Estado, No 21 (2009), pp. 47-68, y Hernández, H., "La introducción de la responsabilidad penal de las personas jurídicas en Chile", Política Criminal, Vol. 5 No 9 (2010), A5, pp. 205-236.
} 
pueda entenderse como una de contaminación. Su configuración legal y, por lo mismo, el principio de legalidad constitucionalmente consagrado no admite tal equiparación.

\subsubsection{1. ¿Comisión por omisión?}

En el concepto de Muñoz y Fernández, para asimilar la figura en estudio a un delito de emisión indebida de contaminantes, se ha transformado la conducta propagar en el resultado de propagación, de tal modo que se transforma el delito de comisión activa en uno "resultativo", que, en sus palabras, "no exige que esa propagación haya de llevarse mediante una acción, sino que es posible que sea fruto de una omisión que queda equiparada a efectos de pena con la acción”, postulando, en consecuencia, la posibilidad de su comisión por omisión, cumpliéndose los requisitos generales previstos para ello ${ }^{39}$.

Sin embargo, el sentido literal posible del texto en estudio no admite esta extensión del ámbito de lo punible por medio de la sustitución del verbo rector de la conducta punible por otra expresión que convenga al interés del intérprete en orden a extender el ámbito de la punibilidad, por loables que sean los fines perseguidos. Si bien se discute entre nosotros que la aplicación a la interpretación de las leyes penales del principio pro reo limite el alcance del artículo 23 del Código Civil, que dispone que "lo favorable u odioso de una disposición no se tomará en cuenta para ampliar o restringir su interpretación", pueda esgrimirse contra una interpretación pro reo en un caso dubitativo, no se discute que, en ningún caso, un principio contrario pueda permitir extender el ámbito de lo punible a voluntad del intérprete. Este resultado transgrede el principio de legalidad del mismo modo que si se quisiera justificar esta consciente extensión del sentido literal posible (en este caso, mediante la sustitución del verbo rector por un sustantivo), alegando el criterio teleológico basado en la protección de los bienes jurídicos en juego, pues este es un argumento que puede considerarse válido solo para limitar el sentido literal posible de la norma, no para su extensión a casos que no comprende ${ }^{40}$.

Luego, si hemos de atenernos al principio de legalidad, habremos de concluir que el verbo rector propagar, en su acepción aplicable a este supuesto, solo permite entenderlo como un hacer positivo, una conducta comisiva, que se describe como bacer que las sustancias susceptibles de poner en peligro la salud animal o vegetal lleguen a otros sitios distintos de aquel en que se producen, y que, por lo tanto, no admite su comisión por omisión, pues por esta vía podrán no evitarse ciertos resultados respecto de los cuales se tendría el deber de evitarlos, pero no puede hacerse algo.

La situación presenta un paralelo interesante con lo que sucede en relación con la imposibilidad legal de la comisión por omisión de los delitos de lesiones graves en el Derecho penal chileno, según afirman Politoff, Bustos y Grisolía:

39 Muñoz y Fernández, "Estudio", p. 433. En el mismo sentido, pero sin ofrecer argumentos en que apoyar su opinión, se pronuncia Bullemore, Curso, Vol. III, p. 256.

${ }^{40}$ Matus, Interpretación, pp. 205 a 208. 
“Conceptualmente es posible lesionar por omisión, tanto como matar por omisión. Sin embargo, en un tipo de lesiones no delimitado en su conducta (por ejemplo, en el Código Argentino), tal asimilación podría aplicarse ampliamente. Ello no puede decirse frente a la ley chilena, ya que las conductas de herir, golpear, maltratar de obra y la de administrar sustancias o bebidas nocivas son inequívocamente activas, de tal manera que no podrían ser incriminadas, por el título de lesiones graves, aquellas lesiones, por importante que fuere su resultado, en que la conducta del agente consista en una omisión" ${ }^{41}$.

$\mathrm{Y}$ aunque autores como Garrido discuten estas conclusiones, lo hacen no por estar en contra del argumento de fondo, esto es, que, una conducta descrita por la ley de manera activa no se puede transformar en omisiva por voluntad del intérprete, sino por entender que los verbos rectores no están limitados a un obrar activo en ese caso en concreto (artículo 397 del Código Penal) ${ }^{42}$.

En cambio, en el caso del artículo 291 del Código Penal, para admitir su comisión por omisión no basta una comprensión diferente del sentido del verbo rector de la figura propagar, sino que es necesaria su consciente sustitución por el sustantivo propagación. En efecto, solo esta sustitución, que prohíbe la garantía del principio de legalidad, permite afirmar la posibilidad de una comisión por omisión en este caso, como lo demuestra un sencillo análisis de los significados de las expresiones en juego.

Como ya hemos señalado, el verbo propagar está definido por el Diccionario como un hacer que algo llegue a un sitio diferente del cual se produce.

En cambio, el sustantivo propagación, según el Diccionario, importa algo más que la conducta base, sino también su resultado: acción y efecto de propagar.

Ese efecto es el que puede desvincularse de una conducta humana de propagar. Así, por ejemplo, sucede con el expreso castigo de la "propagación" culposa de enfermedad plaga en el artículo 289, inciso segundo, del Código Penal: una conducta descuidada puede hacer posible que animales enfermos transmitan sus enfermedades a otros sanos, esto es, que se produzca "el efecto de propagar" una enfermedad sin que un ser humano la propague. En este caso, la forma de la conducta es indiferente, en la medida que represente un descuido que haga posible la "propagación".

Pero el artículo 291 del Código Penal no castiga la propagación, sino el propagar. $\mathrm{Y}$, por lo tanto, la acción no es indiferente y solo puede sancionarse aquella contemplada en la ley: hacer que algo se extienda o llegue a sitios distintos de aquel en que se produce. Y esta descripción de la conducta como una "hacer" no admite por su solo tenor literal ni su comisión culposa ni su comisión por omisión.

Luego, una extensión de la tipicidad mediante la consciente sustitución del verbo rector "propagar" con el sustantivo "propagación” deriva en una interpretación extensiva

${ }^{41}$ Politoff, S.; Bustos, J.; y Grisolía, F., Derecho penal chileno. Parte especial, Santiago: Ed. Jurídica de Chile, 1971, p. 289.

${ }^{42}$ Garrido, M., Derecho penal. Parte especial, T. III, 4ª ed., Santiago: Ed. Jurídica de Chile, p. 158. 
del delito del artículo 291 del Código, lo que, como dijimos, prohíbe no solo el artículo 24 del Código Civil, sino también, y sobre todo, el $19 \mathrm{~N}^{\circ} 3$, inciso $8^{\circ}$ de la Constitución, al consagrar la garantía del principio de legalidad.

1.3.3. Objeto material de la conducta: sustancias "susceptibles de poner en peligro la salud animal o vegetal o el abastecimiento de la población”

El objeto material de la conducta, esto es, la cosa o cosas sobre las que recae la conducta típica, son, en esta figura, los “organismos, productos, elementos o agentes químicos, virales, bacteriológicos, radiactivos, o de cualquier otro orden susceptibles de poner en peligro la salud animal o vegetal o el abastecimiento de la población" que se propagan.

Como hemos anticipado, es en la configuración de este elemento del tipo penal donde radica la lesividad del delito, en el sentido de la afectación a los bienes jurídicos protegidos. Las sustancias a que se refiere la ley deben, por su propia naturaleza, ser capaces, sin intervención humana, de poner en peligro la salud animal o vegetal o el abastecimiento de la población.

Al respecto, lo primero que debemos decir es que la naturaleza de algo es, según el Diccionario, su "esencia y propiedad característica" ( $1^{a}$ acepción), esto es, lo que lo distingue de los otros seres, su "especie, género, clase" (13 a acepción).

Por lo tanto, se debiera descartar la posibilidad de cometer este delito por medio de la acumulación de sustancias que por su naturaleza no son susceptibles de poner en peligro la salud animal o vegetal o el abastecimiento de la población, pues esa característica se encuentra exigida expresamente por el texto legal ${ }^{43}$.

Así, por ejemplo, los virus y bacterias a que se refiere el artículo 291 del Código Penal, en tanto producen enfermedades infectocontagiosas en los animales y plagas en las especies vegetales, son, por su propia naturaleza, susceptibles de poner en peligro la salud animal o vegetal o el abastecimiento de la población en general, según los hemos definido en el apartado anterior, al poner en riesgo la supervivencia y productividad de las especies que constituyen la masa pecuaria y vegetal del país. Del mismo modo, debe considerarse dentro de la definición del tipo del artículo 291 del Código Penal, la propagación indiscriminada de otros organismos en la población animal o vegetal, como los priones que originan las encefalopatías espongiformes transmisibles, que respecto del ganado bovino se conoce comúnmente como el mal de las "vacas locas" ${ }^{4}$ o los fitoplasmas, hongos, nematodos y plantas parasíticas que causan enfermedades y daños a

${ }^{43}$ Por ello es errada la asimilación que Muñoz y Fernández, "Estudio”, p. 438, hacen entre este artículo 291 de nuestro Código Penal y el artículo 325.1 del Código Penal español, recientemente modificado por el artículo único, $\mathrm{N}^{\circ}$ 92, de la Ley Orgánica 5/2010, de 22 de junio y que no hace alusión alguna a la naturaleza del objeto material de la conducta, ni se refiere a la propagación de sustancias determinadas, sino que castiga únicamente la emisión contraria a la regulación vigente, como se desprende de su sola lectura.

${ }^{44}$ Sobre el tema en general, véase Vargas, A.M.; Salto, R.; Sola; y Hortelano, "Encefalopatías espongiformes transmisibles. Bases moleculares, diagnóstico y perspectivas terapéuticas”, Ars Pharmaceutica, Vol. 42, No 1 (2001), pp. 5-20. 
las especies vegetales ${ }^{45}$, en la medida que puedan afectar potencialmente a un número indeterminado de los miembros de una especie animal o vegetal en la zona más o menos amplia de territorio donde se desarrollan, poniendo en peligro su salud.

Lo mismo podría decirse de los elementos radiactivos, esto es, los que "al desintegrarse espontáneamente emiten radiaciones”, los cuales, por su propia naturaleza, en la medida que no se encuentran bajo control técnico, pueden afectar la salud de grupos indeterminados de personas, animales o vegetales en una zona más o menos extensa alrededor del territorio en el que se emite la radiación.

En cambio, tratándose de agentes químicos, que tienen en común con los elementos radiactivos su carácter de ser una "causa abiótica" de enfermedades ${ }^{46}$, es necesario hacer alguna distinción, por cuanto la composición de toda la materia del universo es en sí misma producto de su presencia o combinación, ya que estos pueden definirse como todo elemento o compuesto químico, por sí solo o mezclado, tal como se presenta en estado natural o es producido, utilizado o vertido, incluido el vertido como residuo, se haya elaborado o no de modo intencional ${ }^{47}$.

Luego, son propiamente agentes químicos todos los productos plaguicidas y medicinales, así como los fertilizantes y alimentos para plantas y animales. Pero es evidente que estos, por su naturaleza, no son susceptibles de poner en riesgo la salud animal o vegetal y el abastecimiento de la población, sino al contrario: están destinados a prevenir los daños en la salud animal o vegetal y a optimizar sus capacidades productivas. A este grupo pertenecen, desde luego, los plaguicidas, fertilizantes, medicamentos y alimentos registrados y cuyo uso se encuentra permitido por la autoridad ${ }^{48}$.

Por el contrario, podrían llegar a considerarse peligrosos para la salud animal y vegetal, aquellos plaguicidas, medicamentos, fertilizantes y alimentos preparados cuyo empleo no se encuentre autorizado o se encuentre expresamente prohibido, lo que,

45 Estas son, junto a virus y bacterias, las denominadas “causas bióticas” de las enfermedades en las plantas (Ciampi, Introducción a la Patología Vegetal, p. 22).

${ }^{46}$ Ciampi, Introducción a la Patología Vegetal, p. 22. Esta vinculación no debe hacernos perder de vista, sin embargo, que las enfermedades vegetales, en tanto afectación a la salud individual de las plantas, solo significan también una afectación de la salud vegetal, en la medida que su propagación abarque zonas más o menos extensas del territorio y afecte a un grupo indeterminado de individuos de una especie animal o vegetal.

${ }^{47}$ La definición se ha planteado tomando como referencia, con las adecuaciones pertinentes, el artículo 2 , letra a) de la Directiva 98/24/CE del Consejo de 7 de abril de 1998 relativa a la protección de la salud y la seguridad de los trabajadores contra los riesgos relacionados con los agentes químicos durante el trabajo.

${ }^{48} \mathrm{Y}$ ello, aunque en su uso no se respeten las dosificaciones correspondientes o se abuse de los mismos (lo que podría eventualmente dañar la salud individual de las plantas afectadas, pero sin poner en verdadero peligro la salud vegetal de la especia) o, como es más común, se ponga con ello en riesgo la salud de las personas que los manipulan o los reciben por cualquier vía, para evitar las regulaciones correspondientes (así, por ejemplo, los artículos 32 y siguientes del Decreto Ley $\mathrm{N}^{\circ} 3.557$, que regula la rotulación, empleo y desecho de plaguicidas y el Decreto Supremo No 594, publicado el 29 de abril de 2000, sobre Condiciones Sanitarias y Ambientales en los lugares de trabajo). En estos casos, el peligro para la vida animal y vegetal es inexistente o proviene de una errónea aplicación de agentes que, por su naturaleza, son beneficiosos, al punto de encontrar en los registros respectivos, con independencia, que puedan ser peligrosos para los seres humanos en contacto con ellos. 
atendido el carácter de delito de peligro concreto de esta figura, siempre se deberá demostrar pericialmente ${ }^{49}$.

Respecto del resto de las "sustancias" a que se refiere la ley, ellas pueden ser asimiladas a los agentes químicos, debido a su amplia definición, aplicándoseles las mismas ideas, con la siguiente variación: en la medida que su producción, tenencia o propagación no exija una autorización o permiso de la autoridad por razones de sanidad animal o vegetal, ni esté expresamente prohibida por las mismas causas, ha de suponerse, prima facie, que se trata de sustancias inocuas para la salud animal o vegetal.

Ello nos permite afirmar que no pueden considerarse como sustancias que ponen en peligro la salud animal o vegetal, todas aquellas que se encuentran naturalmente sobre la corteza terrestre sin haber sido objeto de un proceso productivo de transformación o elaboración que altere su composición química, pues ellas constituyen el ambiente donde se desarrolla la vida animal y vegetal, siempre que el resto de las condiciones para ello se encuentre también presente (temperatura, presión atmosférica, recursos hídricos, etc.).

Para graficar este punto, tomemos el ejemplo del polvo en suspensión que se levanta al transitar sobre caminos de tierra y se deposita sobre las plantas a la vera del camino: su breve desplazamiento, producto de la acción del viento, no es una propagación propiamente tal, y a menos que se quiera alterar el sentido de la realidad, no puede decirse que la tierra sobre la que nos desplazamos sea, por su naturaleza, peligrosa para la salud animal o vegetal. Y ello, aun cuando su acumulación permanente sobre ciertas plantas o su inhalación en grandes cantidades por animales determinados, pueda, eventualmente, causar daños a la salud individual de los especímenes expuestos, según sus propias condiciones biológicas de tolerancia a tal exposición. Solo en casos verdaderamente catastróficos, como erupciones volcánicas, la propagación de los componentes químicos naturales de la corteza terrestre podría considerarse un peligro para la salud animal y vegetal de las especies que ocupan las zonas más o menos extensas sobre las cuales se propagan y depositan repentinamente grandes cantidades de polvo, cenizas y demás elementos que provienen de la erupción. Afortunadamente, estos fenómenos no pueden ser, por el momento, reproducidos por la actividad humana.

Por lo tanto, para considerar prima facie como peligrosa para la salud animal o vegetal una sustancia presente en la naturaleza que no sea un virus, bacteria, organismo vivo transmisor de enfermedades o plagas o elemento radiactivo, debiera existir al menos un listado de constituyentes químicos similar al que la Organización Mundial de la Salud ha propuesto con relación a la salud humana ${ }^{50}$, que determinase los límites tolerables

${ }^{49}$ En los casos concretos, habrá todavía de distinguirse, por lo tanto, si la prohibición se ha establecido en orden a proteger la salud pública humana o la salud vegetal o animal, pues ciertos productos inocuos o beneficiosos para las segundas pueden ser nocivos para la salud humana. En tales casos no estaremos en presencia de un delito del artículo 291 del Código Penal, sino, eventualmente, de alguno de sus artículos 314 a 317 , de cumplirse los requisitos de los tipos correspondientes (véase al respecto, Zepeda, M.; Scheider. S.; Celis, R., Los delitos contra la salud pública y el tráfico ilícito de estupefacientes, Santiago: Tesis UCh, 1974, pp. 40-59).

50 Véase al respecto Chung, B., "Control de los contaminantes químicos en Perú", Revista Peruana de Medicina Experimental y Salud Pública, Vol. 25, No 4 (2008), pp. 413-418, p. 413, y la página web del International Programme on Chemical Safety de la Organización Mundial de la Salud (http://www.who.int/ipcs/en/) 
de los mismos que, emitidos en un momento determinado, sean susceptibles de poner en peligro la salud animal o vegetal.

Debido a que estos listados no existen, en un caso concreto, para considerar como peligrosa para la salud animal o vegetal sustancias que no estén autorizadas o se hayan prohibido por razones de sanidad animal o fitosanitarias, se debería demostrar que las sustancias en cuestión constituyen efectivamente un peligro para la salud de un número indeterminado de especies vegetales o animales en una zona más o menos extensa del territorio que ocupan ${ }^{51}$.

\subsubsection{El actuar "indebido" como una forma de establecer una ley penal en blanco}

Como se ha anticipado, el tipo penal del artículo 291 del Código del ramo no castiga todo hacer llegar a un lugar diferente del que se producen o encuentran sustancias susceptibles por su propia naturaleza de poner en peligro la salud animal o vegetal o el abastecimiento de la población, sino solo tales conductas cuando se realicen de manera indebida.

Una conducta indebida es, según el Diccionario, aquella que no es obligatoria ni exigible.

En este caso en particular, existiendo el principio general de la libre empresa, consagrado en el artículo $19 \mathrm{~N}^{\circ} 21$ de la Constitución como "el derecho a desarrollar cualquiera actividad económica que no sea contraria a la moral, al orden público o a la seguridad nacional, respetando las normas legales que la regulen", lo obligatorio y exigible, en relación con el propagar sustancias que, por su naturaleza, puedan poner en peligro la salud animal o vegetal, debe determinarse necesariamente por la existencia de disposiciones normativas que así lo establezcan expresamente.

Y como lo obligatorio o exigible solo puede estar en relación con lo mandado por el ordenamiento jurídico en un caso determinado, este elemento normativo adicional confiere a la disposición en estudio el carácter de ley penal en blanco ${ }^{52}$. Por ello, Muñoz y Fernández

${ }^{51}$ Según añaden Muñoz y Fernández, "Estudio”, p. 438, se debiera exigir además que este peligro, que ellos califican de hipotético, sea grave, en el sentido que ha sido desarrollado por la doctrina española con base al principio de lesividad y la ratio legis del artículo 325 de su Código Penal (lo que significa tomar en cuenta la mayor o menor probabilidad de la ocurrencia de la lesión del bien jurídico, su extensión en el espacio, la prolongación en el tiempo de la misma y la intensidad de la afección o incidencia efectivamente comprobada). Por nuestra parte, ya hemos dicho en una nota anterior ( $\mathrm{N}^{\circ} 43$ ) que esta asimilación entre el delito ecológico del Código Penal español y la figura de nuestro artículo 291 es inapropiada, por lo que estas restricciones son innecesarias, ya que buena parte de ellas se encuentran ínsitas en el concepto de bien jurídico protegido por estos delitos antes desarrollado, que no es el medio ambiente (como en la figura española) ni la salud individual o la suma de afectaciones a la salud de un número determinado de especímenes de una especie vegetal o animales, sino la salud de la especie vegetal o animal en una zona más o menos extensa del territorio, cuya afectación importa una significativa disminución de su número o productividad, y que, por lo tanto, no debe considerarse el delito solo como un caso especial de contaminación ambiental, como hace el modelo español al que ellos se refieren.

52 En efecto, según se lee en Politoff, Matus y Ramírez, Parte General, p. 184, la expresión indebidamente se puede describir también como un elemento normativo del tipo que hace referencia a la antijuricidad y que, por lo tanto, "debe entenderse como un llamado de atención a que puede haber reglas de derecho 
afirman con razón que "para entender consumado el tipo se requiere una vulneración de la norma extrapenal, normalmente una norma administrativa" ${ }^{53}$, donde se encontrarían establecidas las obligaciones y limitaciones cuya infracción haría indebida la conducta de que se trata.

El empleo de estas leyes penales en blanco para delimitar el ámbito de lo punible ha sido reconocida como válida por nuestra doctrina ${ }^{54}$ y el propio Tribunal Constitucional, desde su fallo en la causa Rol No 24-84, de 19 de noviembre de 1984, que lo declaró conforme a la garantía del artículo $19 \mathrm{~N}^{\circ} 3$, inciso $8^{\circ}$, de la Constitución. Allí se expresó que para el cumplimiento de dicha garantía es suficiente "que la conducta que se sanciona esté claramente descrita en la ley, pero no es necesario que sea de un modo acabado, perfecto, de tal manera llena, que se baste a sí misma en todos sus aspectos no esenciales", agregando que lo relevante es que "el núcleo esencial de la conducta que se sanciona esté expresa y perfectamente definido”.

Debido a que el artículo 291 del Código Penal describe expresamente la conducta punible, puede entenderse conforme con la exigencia constitucional. El problema relevante que surge, en consecuencia, es determinar cuáles y qué clase de normas podrían ser admisibles para su delimitación, que no es otra cosa que la precisión del ámbito de lo punible en la materia.

Según nuestro Tribunal Constitucional, lo esencial de la garantía constitucional que aquí está en juego es asegurar al hombre la facultad de actuar en sociedad con pleno conocimiento de las consecuencias jurídicas de sus actos (STC Rol N ${ }^{\circ}$ 1.191-2008, considerando $14^{\circ}$ ). Luego, lo que determina en un caso concreto la satisfacción de esta exigencia no es solo la exigencia de contemplar el núcleo fundamental de la conducta en la ley penal, sino también que la norma remitida exista como tal, no quedando entregada la determinación de la conducta punible al criterio discrecional del juez (STC Rol $\mathrm{N}^{\mathrm{o}} 1.011-07$ considerandos $14^{\circ} \mathrm{y} 18^{\circ}$ ), y tenga la entidad o densidad normativa suficiente para cumplir con la exigencia constitucional. Esto último importa tanto un requisito material, esto es, que la norma remitida no complemente la disposición con expresiones vagas e imprecisas; como uno formal, en el sentido que dicha norma debe ser producto del ejercicio de la potestad reglamentaria del Poder Ejecutivo, debiendo por tanto emitirse

\footnotetext{
público o privado que pueden conceder a esa conducta legitimidad, cuya existencia debiera ser averiguada en sede procesal antes de decretarse alguna medida que suponga la existencia del hecho punible”. La cuestión relevante es determinar dicha normativa, por lo que, visto desde esta perspectiva, también se trata de un problema de la ley penal en blanco y la determinación de las normas a que remite. En cambio, no es correcto afirmar, como hace Bullemore, Curso, Vol. 3, p. 456, que la expresión "indebidamente" haga referencia a la exclusión de la figura culposa, por dos razones principales: primero, porque ello no es acorde con el sentido literal de la expresión “indebidamente”, según se expuso arriba en el texto; y segundo, porque no existiendo entre nosotros un sistema de numerus apertus o crimen culpae mediante una cláusula general aplicable a todos los delitos, la ley no necesita emplear ninguna expresión especial para excluir la posibilidad de comisión culposa de un delito determinado: al revés, lo que la ley necesita es señalar expresamente los casos de delitos culposos (artículo $10 \mathrm{~N}^{\circ} 13$ del Código Penal).

53 Muñoz y Fernández, "Estudio”, p. 425.

${ }^{54}$ Véase, por todos, Cury U., E., La ley penal en blanco, Bogotá: Temis, 1988, p. 63.
} 
en la forma de un Decreto Supremo y no bajo otros mecanismos como son los decretos exentos (STC Rol N $\mathrm{N}^{\circ}$ 781-07, considerando $17^{\circ}$ ) u otros actos de la administración.

Según Muñoz y Fernández, la expresión “indebidamente” del artículo 291 del Código Penal contendría una referencia normativa que iría más allá de las exigencias de las leyes penales en blanco propias, como hasta aquí se han expuesto, afirmando que la infracción a la norma extrapenal que delimita el alcance del delito del artículo 291 del Código Penal, "no podemos circunscribirlo de manera exclusiva a una norma escrita extrapenal, sino también, [puede extenderse] a la costumbre profesional (Lex artis)”, pues "el precepto se sitúa entre un tipo abierto y una ley penal en blanco" 55.

Al respecto cabe decir lo siguiente: primero, que el Tribunal Constitucional no admite como legítimos los llamados tipos penales o leyes penales abiertas, en las cuales la determinación del ámbito de lo punible queda entregada al juez, como expresamente lo señala en la STC 26.08.2008, causa Rol $N^{0} 1.011-07^{56}$. Y en segundo lugar, que si bien la ley penal da lugar a inclusión de la lex artis como fundamento de la responsabilidad penal, por ejemplo, en el delito de negligencia médica del artículo 491 del Código Penal, ello se hace, precisamente, para determinar el ámbito de lo prudente del de lo imprudente. En tales casos, la ley impone expresamente una sanción al actuar negligente y para determinar cuándo estamos ante dicha situación se recurre a la comprobación de si se ha actuado o no con el debido cuidado, identificando este con el cumplimiento de los protocolos y demás exigencias de la lex artis $^{57}$. Pero tal situación no es equivalente a la de un delito cuyo comportamiento es doloso complementado por una remisión normativa. En tales casos, el Tribunal Constitucional ha sostenido, como hemos expuesto detalladamente, que las regulaciones reglamentarias que complementan una figura penal que hace referencia a incumplimiento de deberes ("lo indebido") deben existir como tales y poseer un grado de generalidad que va más allá de una simple resolución administrativa, exigiendo específicamente la existencia de un Decreto Supremo de carácter general que las establezca.

55 Muñoz y Fernández, "Estudio, p. 425.

${ }^{56}$ Cuyo Cons. $4^{\circ}$ reza: "Que, sin perjuicio de lo anteriormente descrito, esta Magistratura ha sentenciado que al establecer la reserva legal de la descripción de la conducta punible en el octavo inciso del numeral $3^{\circ}$ del artículo 19, con la fórmula "expresamente", la Constitución ha garantizado el principio jurídico fundamental "no hay delito ni pena sin ley", pero, asimismo, ha tolerado la existencia de las denominadas leyes en blanco impropias o de reenvío, esto es, aquellas cuya remisión para describir la conducta punible se encuentra en otra ley o en una norma originada en la instancia legislativa, y de aquellas leyes que indiquen expresamente la norma destino de remisión aun cuando no sea de origen legislativo, con descripción del núcleo central de la conducta que se sanciona. Esta delimitación significa que serán contrarias al precepto constitucional señalado las denominadas leyes penales en blanco propias y las leyes penales en blanco abiertas, esto es, aquellas en que la descripción de la conducta está entregada a una norma infralegal sin indicar legalmente el núcleo fundamental de ella, y las que entregan la determinación de la conducta punible al criterio discrecional del juez".

${ }^{57}$ Matus, J.P., "Mala praxis como sinónimo de negligencia y la «normativización» de la responsabilidad penal médica en la reciente jurisprudencia de la Corte Suprema de Chile ¿un camino hacia la responsabilidad penal objetiva?", en Microjuris, MJCH_MJD362-2009. 
Corresponde ahora determinar cuáles serían las normas reglamentarias que complementan la conducta descrita en el artículo 291 del Código Penal para que ella pueda considerarse indebida.

Al respecto, cabe señalar que en la regulación vigente destinada a la protección a la salud animal y vegetal recopilada por el Servicio Agrícola y Ganadero existen disposiciones del rango exigido por el Tribunal Constitucional sobre las siguientes materias:

- Decreto Ley No 3.557, de 1980, que establece disposiciones generales sobre protección agrícola, regulando la prevención, control y combate de plagas, incluyendo la importación y exportación de especies vegetales, la fabricación, comercialización y aplicación de plaguicidas y fertilizantes, y sobre la protección a los trabajadores en el uso de productos fitosanitarios;

- Ley de Sanidad Animal, Decreto con Fuerza de Ley R.R.A.A. No 16, de 1963, que establece disposiciones sobre la internación, tránsito y exportación de animales, denuncia y control de enfermedades infectocontagiosas, y marcas de animales vacunos y caballares;

- Decreto Supremo No 664, de 5 de octubre de 1939, que reglamenta las exposiciones ganaderas;

- Decreto Supremo No 318, de 1925, que reglamenta "la aplicación de la lei de Policia Sanitaria Animal”, fijando las enfermedades infectocontagiosas sometidas a control y las medidas aplicables en cada caso;

- Reglamento de productos farmacéuticos de uso veterinario, Decreto Supremo $\mathrm{N}^{\circ} 25$ de 2005;

- Reglamento de alimentos para animales, Decreto Supremo No 307, de 1979.

Como la sola mención de sus títulos y contenido indica, la normativa reseñada puede complementar el contenido del artículo 291 del Código Penal, principalmente en lo referido a la delimitación de los virus, bacterias y otros organismos vivos transmisores de plagas y enfermedades que ponen en peligro la salud vegetal o animal; así como de los agentes y sustancias químicas destinadas a la producción de alimentos y productos medicinales cuyo empleo pudiera prohibirse por ser peligroso para la salud animal o vegetal $^{58}$, pero no en lo relativo al material particulado sedimentable.

Solo el Decreto Ley $\mathrm{N}^{\circ} 3.557$ ha contemplado en su artículo 11 un principio de regulación amplio de las sustancias que, de ser propagadas, podrían poner en peligro la

58 De allí que, por ejemplo, de dicha normativa surge que si se propagan plaguicidas o productos medicinales debidamente autorizados para la contención o prevención de una plaga o epidemia animal, tanto en los casos en que ello se hace voluntariamente como cuando a su realización se es forzado por la autoridad en situaciones de emergencia sanitaria, este hecho no será nunca típico, aun cuando, por su naturaleza, los compuestos o agentes químicos de los mismos pudieran, eventualmente, ser susceptibles de poner en peligro la salud animal o vegetal, si se emplean respecto de otras especies o en otras zonas donde no sean necesarios. 
salud vegetal, si entendemos que ello podría ser un caso específico de "contaminación"59 "procedente" de "establecimientos industriales, fabriles, mineros y cualquier otra entidad que manipule productos susceptibles de contaminar la agricultura”, señalando que tales establecimientos "deberán adoptar oportunamente las medidas técnicas y prácticas que sean procedentes a fin de evitar o impedir la contaminación” (artículo 11, inc. $1^{\circ}$ ).

Sin embargo, esta norma no establece cuáles habrían de ser esas "medidas técnicas y prácticas que sean procedentes a fin de evitar o impedir la contaminación”, con lo que la norma queda completamente abierta y no cumple la exigencia de "densidad normativa" que impone el Tribunal Constitucional para admitir como válida la remisión que se haría desde la expresión “indebidamente” del artículo 291 del Código Penal. Tampoco consta que se haya dictado por el Ministerio de Agricultura un Decreto Supremo regulando la materia.

Es más, tampoco se ha dictado a la fecha el Decreto Supremo que el inciso segundo de dicho artículo 11 prevé debiera dictarse por el Presidente de la República para hacer exigible la obligación a "dichas empresas" de "tomar las medidas tendientes a evitar o impedir la contaminación” en el "plazo prudencial” que "para la ejecución de las obras" se establezca ${ }^{60}$.

Por su parte, el Decreto Supremo No 185 (Ministerio de Minería), de 16 de enero de 1992, que reglamenta el funcionamiento de establecimientos emisores de anhídrido sulfuroso, material particulado y arsénico en todo el territorio de la República, establece en su artículo $7^{\circ}$ que una Comisión Interministerial podrá proponer al Ministerio de Agricultura la dictación de un Decreto Supremo que contenga las normas secundarias de calidad ambiental, esto es, las que establecen las concentraciones ambientales máximas permisibles para anhídrido sulfuroso y para material particulado y que tienen por objeto preservar los ecosistemas y proteger las explotaciones silvoagropecuarias (artículo $3^{\circ}$, letra 1 ), que regirá en áreas con actividad silvoagropecuaria o recursos naturales renovables, considerando la concentración máxima permitida de estos y de los elementos químicos que lo componen, así como la localización de su aplicación y los procedimientos para su medición.

${ }^{59}$ Nótese que esto no significa que afirmemos que toda forma de contaminación sea asimilable a propagar las sustancias a que se refiere el artículo 291 del Código Penal, sino que este hecho puede verse como un caso específico o especial de un concepto amplio de contaminación, donde se incluyen hechos que no constituyen necesariamente la propagación de que habla dicho artículo, sino también, principalmente, la emisión de contaminantes sin necesidad de un hacer activo que los traslade a otro sitio, como exige la voz propagar.

${ }^{60}$ Como tal reglamentación no existe, parecen también inaplicables las facultades que se conceden en el inciso tercero del artículo $11^{\circ}$ al Presidente de la República para, "en casos calificados” (que no están expresados), "ordenar la paralización total o parcial de las actividades y empresas artesanales, industriales, fabriles y mineras que lancen al aire humos, polvos o gases, o que vacíen productos y residuos en las aguas, cuando se comprobare que con ello se perjudica la salud de los habitantes, se alteran las condiciones agrícolas de los suelos o se cause daño a la salud, vida, integridad o desarrollo de los vegetales o animales". Lo mismo ocurriría si un juez en lo civil, conociendo la acción de un particular interpuesta en conformidad con el artículo 12 de dicho cuerpo legal, remitiese al Ministerio de Agricultura los antecedentes del proceso, por estimar que "la contaminación afectare en forma grave a la agricultura de una zona o región". 
En uso de estas facultades, solo se ha dictado un Decreto Exento que establece normas de calidad del aire para material particulado sedimentable en la cuenca del río Huasco, III Región (Decreto Exento No 4, publicado el 4 de mayo de 1992), el que, con todo, no cumple el requisito de ser un Decreto Supremo, según lo establece el Tribunal Constitucional para servir de complemento a una ley penal en blanco, como es el artículo 291 de Código Penal en su referencia al actuar indebido ${ }^{61}$.

Además, se debe tener en cuenta que las normas de calidad ambiental no son normas de emisión, es decir, no establecen límites máximos de emisión por fuente, de modo que no son de aplicación directa y no puede decirse en relación con ellas que una fuente determinada emite indebidamente una cantidad de contaminantes, pues dichas normas no tienen por objeto fijar normas de emisión, sino la meta de gestión ambiental para la elaboración de los planes de descontaminación respectivos, para el territorio que aplican y el conjunto de las fuentes allí existentes (principio de acumulación). Y que no todas las normas de calidad ambiental se refieren a la salud vegetal o animal: a ellas solo están referidas las normas secundarias, según lo expresado más arriba. En cambio, las normas primarias de calidad ambiental fijan metas de gestión ambiental en relación con la salud pública bumana en el territorio en que se aplican, es decir, se trata de normas que "establecen el nivel de riesgo a que están expuestos los chilenos, frente a la presencia de contaminantes atmosféricos" y, por lo mismo, "son también el objetivo o meta de la gestión ambiental, y frente a su incumplimiento se establecen planes de prevención de la contaminación o planes de descontaminación, que a su vez disponen las medidas para recuperar la calidad ambiental deteriorada" 62 , pero no establecen niveles permitidos o no permitidos para fuentes de emisión específicas.

Para estos efectos, desde la creación de la Comisión Nacional del Medio Ambiente, hoy Ministerio del ramo, se han ido dictando varias normas de emisión para determinadas sustancias en las hoyas hidrográficas, regiones y localidades que allí se indican, las que, de relacionarse con la normas secundarias de calidad ambiental, podrían eventualmente servir de complemento, en su ámbito de aplicación, a las disposiciones del artículo 291 del Código Penal, siempre que las sustancias reguladas, por su naturaleza, sean susceptibles de poner en peligro la salud animal o vegetal o el abastecimiento de la población. Esto último debe tenerse especialmente en cuenta a la hora de recurrir a las normas de emisión del sistema de gestión del medio ambiente, pues, como ya se dijo, ellas están dispuestas bajo el paradigma de la acumulación en relación con las normas de calidad

${ }^{61}$ En cambio, sí se han fijado normas primarias de calidad del aire relativas a material particulado en suspensión y, específicamente, al denominado MP10. Estas normas no aplican, sin embargo, a la interpretación de este artículo 291 del Código Penal, porque ellas dicen relación con la salud pública (bumana), esto es, "establecen los valores de las concentraciones y períodos, máximos o mínimos permisibles de elementos, compuestos, sustancias, derivados químicos o biológicos, energías, radiaciones, vibraciones, ruidos o combinación de ellos, cuya presencia o carencia en el ambiente pueda constituir un riesgo para la vida o la salud de la población" (artículo $2^{\circ}$, letra n), Ley $N^{\circ} 19.300$ ), como el Decreto Supremo N $^{\circ} 59$ (Ministerio de Salud) de 1998.

${ }^{62}$ Matus C., P.; Lucero, R., "Norma primaria de calidad del aire”, Revista chilena de enfermedades respiratorias, Vol. 18, No 2 (2002), pp. 112-122, p. 112s. 
primarias o secundarias fijadas para un determinado territorio. Y por lo tanto, no se trata de regular específicamente cantidades de emisiones de sustancias que, por su naturaleza, sean susceptibles de poner en peligro la salud animal o vegetal o el abastecimiento de la población. Lo que significa que las cantidades permitidas o prohibidas puede que, por su naturaleza, no constituyan ese peligro, pero la autoridad las fija en ese punto, atendida la conformación de la hoya hidrográfica donde se encuentran las fuentes emisoras y la norma de calidad secundaria a que se quiere llegar. Como ya explicamos, esta es una consecuencia de la configuración del artículo 291 del Código Penal como un delito de peligro concreto para la salud vegetal o animal y no de uno de contaminación propiamente tal, donde el paradigma de la acumulación es aplicable de manera casi directa ${ }^{63}$.

Adicionalmente, tampoco existen normas de emisión aplicables en todo el territorio nacional para toda clase de sustancias, y particularmente, no las hay para el material particulado que proviene de las actividades de traslado y chancado de minerales ${ }^{64}$.

Por lo tanto, respecto de todas las sustancias no reguladas expresamente en las disposiciones legales y reglamentarias destinadas a la protección de la salud animal o vegetal anteriormente enumeradas, no existe normativa complementaria que establezca las condiciones en que la conducta de propagarlas pueda calificarse de debida o indebida, por poner en riesgo la salud animal o vegetal, según lo prescrito en el artículo 291 del Código Penal, por lo que su aplicación a casos no regulados infringiría la garantía constitucional del principio de legalidad, establecida en el artículo $19, \mathrm{~N}^{\circ} 3$, inciso $8^{\circ}$, de conformidad con la jurisprudencia de nuestro Tribunal Constitucional.

\section{CONCLUSiOnes}

Carácter no constitutivo del delito del artículo 291 del Código Penal de la emisión de material particulado producto del transporte y chancado de mineral de cobre, que es depositado por acción del viento en un predio colindante.

${ }^{63}$ Véase al respecto, con referencia al Derecho alemán donde este paradigma opera, Hefendehl, R., “Derecho penal ambiental: ¿por qué o cómo?”, Estudios Públicos, No 110 (2008), pp.165-192, p. 171.

${ }^{64}$ Las únicas normas de emisión aplicables a material particulado existentes son las siguientes: i) las que regulan las fuentes estacionarias puntuales que emitan más de una tonelada diaria de material particulado que se encuentren ubicadas dentro de la Región Metropolitana (DS N ${ }^{\circ} 1538$, Salud, publicado el 26 de abril de 1993); ii) las aplicables a las fuentes estacionarias puntuales y grupales que se encuentren ubicadas dentro de la Región Metropolitana, exceptuando las fuentes estacionarias puntuales que emitan más de una tonelada diaria de material particulado.

El Decreto Supremo No 144 , de 1961, en cambio, no establece una norma de emisión que determine la cantidad indebida de emisión de polvos y humos a la atmósfera, sino solo contiene una prohibición genérica que es desplazada por los permisos y autorizaciones de funcionamiento también genéricos, está destinado a la protección de la salud humana y, como se desprende de su lectura, regula más bien los efectos de la combustión de combustibles sólidos antes que la protección de la salud animal o vegetal. 


\subsection{Inexistencia de la conducta de "propagar" en el hecho de chancar cobre}

Como hemos dicho en la primera parte de este informe, la sola emisión de material particulado producto del chancado de cobre no constituye la conducta típica descrita en el artículo 291 del Código Penal como propagar.

En efecto, si ninguna acción humana puede describirse como hacer que el material particulado emitido por una planta chancadora se extienda o llegue a sitios distintos de aquel en que se emite, entonces lo que tenemos es emisión de tales sustancias, pero no su propagación, que es lo sancionado penalmente.

De los hechos de la naturaleza, como la acción del viento y las condicionantes geográficas, no es posible hacer responsable a personas determinadas, salvo que tales circunstancias puedan de alguna manera ser controladas y exista tal obligación legal, ${ }^{65}$ como si una planta chancadora se emplazase en un lugar determinado como una suerte de instrumento para, aprovechando las condiciones eólicas y geográficas, propagar el material particulado que emite a un predio colindante. Como ese no es el caso de las plantas existentes en Chile, emplazadas donde se emplazan por otras consideraciones, no es posible asimilar la simple emisión del material que producen con su propagación, sin forzar la aplicación del tipo penal.

En tales casos se trata, más bien, de un becho de la naturaleza y no de un acto positivo de un ser bumano en orden a hacer que las sustancias susceptibles de poner en peligro la salud animal o vegetal lleguen a otros sitios distintos de aquél en que se producen.

De donde se desprende que en los hechos por los que se me consulta no se realiza el tipo penal del artículo 291 del Código del ramo.

\subsection{El problema del objeto material del delito}

El material particulado emitido por las plantas chancadoras de cobre no es, por su naturaleza, de aquellas sustancias susceptibles de poner en peligro la salud animal o vegetal.

Por otra parte, supuesto que se admitiese que la actividad de chancar cobre y la emisión del correspondiente material particulado fuese equivalente a lo que la ley describe como propagar tanto de manera activa como omisiva (por no haberse evitado su propagación, estando obligados los operadores a ello), queda por determinar si el material particulado emitido por las plantas chancadoras de cobre es, por su naturaleza, de aquellos susceptibles de poner en peligro la salud animal o vegetal.

De partida, no está de más señalar que dicho material no contiene elementos o agentes radiactivos que pudieran poner en peligro la salud vegetal o animal, en los términos del artículo 291 del Código Penal.

${ }^{65}$ Obligación que objetivamente no existe, pues, como ya hemos señalado, no se han dictado normas generales derivadas del Decreto Ley $\mathrm{N}^{\circ} 3.557$ que impongan obligaciones concretas en tal sentido. 
Y en cuanto a su naturaleza como compuestos químicos, debe señalarse que ellos no afectan, por su naturaleza, la salud animal o vegetal de la zona, pues no se trata de un relave químico, sino exclusivamente del polvo de la tierra que se levanta al transportar y chancar el cobre, mismo polvo que levanta naturalmente el viento.

Esta sola constatación permite afirmar que el material particulado emitido durante el proceso de chancado de cobre no es por su naturaleza, susceptible de poner en peligro la salud animal o vegetal.

\subsection{Atipicidad por falta de normas que establezcan los limites de emisiones permisibles en} la explotación de las plantas de chancado de cobre. Carácter no indebido de estas

Como hemos expuesto en la Primera Parte de este informe, no existen respecto de las explotaciones mineras de las distintas cuencas del país, normas secundarias de calidad ambiental ni normas de emisión de fuentes fijas aplicables, como así tampoco ninguna otra normativa que, teniendo rango al menos de Decreto Supremo, delimite según las exigencias del Tribunal Constitucional el ámbito de lo punible en relación con el peligro para la salud animal o vegetal que pueda representar la emisión de cantidades de material particulado más allá de lo permitido.

Por lo tanto, no existiendo normas que establezcan la medida de lo exigible en esta materia, en atención a la protección de la salud animal o vegetal, no pueden considerarse las emisiones de las plantas chancadoras de cobre como indebidas, en el sentido del artículo 291 del Código Penal y, en consecuencia, no pueden ser sancionadas a ese título sin infringir el principio de legalidad, constitucionalmente reconocido.

\section{BIBLIOGRAFÍA}

BAscuñán R., Antonio, "Comentario crítico a la regulación de los delitos contra el medio ambiente en el Anteproyecto de Código Penal de 2005”, Revista de Estudios Públicos, No 110 (2008), pp. 241-321), especialmente, pp. 292-298.

Bullemore, Vivian, Curso de Derecho Penal, Vol. 3, Santiago: LegalPublishing, 2007.

CÁmara de Diputados, Informe de la Comisión de Constitución, Legislación y Justicia, Diario de Sesiones de la Cámara de Diputados, Sesión 41ª de 5.09.1967, p. 3478.

Casas O., R.; Rosenberg, F.J.; Astudillo, V.M., "La producción y salud animal y sus interrelaciones con la salud pública veterinaria en América Latina y el Caribe", Revue scientifique et technique (International Office of Epizootics), Vol. 10, No 4 (1991), pp. 1087-1100.

Chung, Betty, "Control de los contaminantes químicos en Perú", Revista Peruana de Medicina Experimental y Salud Pública, Vol. 25, No 4 (2008), pp. 413-418.

Ciampi P., Luigi, Introducción a la Patología Vegetal, Valdivia: U. Austral, 2002.

Cury U., Enrique, La ley penal en blanco, Bogotá: Temis, 1988.

Del Río, Raimundo, Derecho penal, T. III, Santiago: Ed. Nascimento, 1935.

Etcheberry, Alfredo, Derecho penal, T.I., $3^{a}$ ed., Santiago, Ed. Jurídica de Chile, 1997.

Garrido M., Mario, Derecho penal. Parte especial, T. III, $4^{a}$ ed., Santiago: Ed. Jurídica de Chile, p. 158. 
Hefendehl, Roland, "Derecho penal ambiental: ¿por qué o cómo?”, Estudios Públicos, $\mathrm{N}^{\circ} 110$ (2008), pp.165-192, p. 171.

Hernández B., Héctor, "La introducción de la responsabilidad penal de las personas jurídicas en Chile", Política Criminal, Vol. $5 \mathrm{~N}^{\circ} 9$ (2010), A5, pp. 205-236.

JunTa de Gobierno, Secretaría de Legislación, Ley $N^{\circ} 18.765$, publicada en el Diario Oficial de 9-12-88, impreso de la Biblioteca del Congreso Nacional.

Matus A., Jean Pierre, “Acerca de la licitud de las 'peleas de gallos' y el alcance del delito del artículo 291 bis del Código Penal”, Gaceta Jurídica, No 370 (2011), pp. 13-24.

Matus A., Jean Pierre (Ed.), Derecho penal del medio ambiente. Estudios y propuesta para un nuevo Derecho penal ambiental chileno, Santiago: Ed. Jurídica de Chile, 2004.

Matus A., Jean Pierre, "Presente y futuro de la responsabilidad de las personas jurídicas por delitos cometidos por sus directivos y empleados", Revista de Derecho del Consejo de Defensa del Estado, No 21 (2009), pp. 47-68.

Matus C., Patricia; Lucero Ch., Rodrigo, "Norma primaria de calidad del aire", Revista chilena de enfermedades respiratorias, Vol. 18, $\mathrm{N}^{\circ} 2$ (2002), pp. 112-122, p. 112s.

Matus, J. P., "Mala praxis como sinónimo de negligencia y la «normativización» de la responsabilidad penal médica en la reciente jurisprudencia de la Corte Suprema de Chile ¿un camino hacia la responsabilidad penal objetiva?”, en Microjuris, MJCH_MJD362-2009

Matus, Jean Pierre, "Fundamentos y propuesta legislativa para una nueva protección penal del medio ambiente en Chile, elaborada por la Comisión Foro Penal”, Zeitschrift für internationales Strafrecht, $\mathrm{N}^{\circ} 7$ (2008), pp. 304-324 (también en Revista de Estudios Públicos, No 110 (2008), pp. 193-239.

Matus, Jean Pierre, La Ley Penal y su Interpretación, 2a . Ed., Santiago: Ed. Metropolitana, 2012.

MuÑoz L., José; Fernández C., José Ángel, "Estudio dogmático penal de los artículos 291 del Código Penal y 136 de la Ley General de Pesca y Acuicultura. A propósito del caso del Santuario de la Naturaleza Carlos Anwandter", Política Criminal, Vol. 5, No 10 (2010), A4, pp. 410-454.

Olea, Andrea, "Zoonosis”, El Vigía. Boletín de Vigilancia en Salud Pública de Chile, Vol. 7, No 19 (2003), pp. 39-43.

Politoff, Sergio; Bustos, Juan; y Grisolía, Francisco, Derecho penal chileno. Parte especial, Santiago: Ed. Jurídica de Chile, 1971, p. 289.

Politoff, Sergio; Matus, Jean Pierre; Ramírez, $\mathrm{M}^{\mathrm{a}}$ Cecilia, Lecciones de Derecho penal chileno. Parte general, $2^{a}$ ed., Santiago: Ed. Jurídica de Chile, 2004, p. 70.

Quiroga J., Scarlet; Troncoso A., Rodrigo, Análisis de delitos de carácter ambiental contenidos en el Código Penal y las leyes especiales chilenas, Tesis UTAL, Talca: 2002 (Prof. Guía: Matus A., Jean Pierre).

Rosenberg, F.J., "Estructura social y epidemiología veterinaria en América Latina", Boletín Panamericano de Fiebre Aftosa, Vol. 52 (1986), pp. 3-23.

Ross, Alf, Sobre el Derecho y la Justicia, Buenos Aires, Eudeba, 1963.

Roxin, Claus, Derecho penal, parte general, $2^{a}$ ed., T. I., Trad. Muñoz Ll. et al, Madrid, Civitas, 1997.

VArGas, AM; Salto, R; Sola; y Hortelano, "Encefalopatías espongiformes transmisibles. Bases moleculares, diagnóstico y perspectivas terapéuticas”, Ars Pharmaceutica, Vol. 42, $\mathrm{N}^{\circ} 1$ (2001), pp. 5-20.

Zepeda R., María; Scheider R., Scarlett; Celis C., Rubén, Los delitos contra la salud pública y el tráfico ilícito de estupefacientes, Santiago: Tesis UCh, 1974. 